ES Jurnal Engineering

\title{
Sistem Monitoring Tegangan, Arus, dan Intensitas Cahaya pada Panel Surya dengan Thingspeak
}

Cahaya Lidya Aritonang ${ }^{1}$, Maison ${ }^{1}$, dan Yosi Riduas Hais ${ }^{1}$

${ }^{1}$ Program Studi Teknik Elektro, Fakultas Teknik, Universitas Jambi, Jambi, Indonesia

Email:cahayacapcai@gmail.com, maison@unja.ac.id, yosiriduashais@gmail.com

\section{Info Artikel}

Diterima: 19 Desember 2019

Disetujui: 14 Januari 2020

Dipublikasikan: 27 Januari 2020

\section{Alamat Korespondensi: \\ cahayacapcai@gmail.com \\ Copyright @ 2020 Jurnal \\ Engineering}

This work is licensed under the Creative Commons Attribution International License (CC BY 4.0).

\begin{abstract}
Abstrak
Penelitian ini bertujuan untuk merancang dan membuat sebuah alat monitoring arus dan tegangan dari panel surya, serta intensitas cahaya matahari yang mempengaruhi keluaran dari panel surya yang berbasis IoT dan bersifat realtime. Data hasil monitoring disimpan dan ditampilkan pada Thingspeak. Penelitian ini menggunakan metode Penelitian dan Pengembangan (Research and Development) model Borg and Gall. Hasil dari penelitian ini adalah nilai pembacaan sensor tegangan mampu mengukur nilai tegangan panel surya dengan nilai galat sebesar $1,12 \%$, sensor arus mampu mengukur arus dengan galat sebesar $1,64 \%$, dan sensor intensitas cahaya BH1750 dalam mengukur intensitas cahaya matahari memiliki persentase galat sebesar $1,24 \%$, kemudian data alat monitoring dikirim dan ditampilkan pada ThingSpeak. Selisih waktu dari pembacaan alat dan data yang diterima oleh website berkisar selam 4-6 detik
\end{abstract}

Kata kunci: sistem monitoring, panel surya, ThingSpeak, monitoring daya, arus, tegangan.

\section{Pendahuluan}

Penggunaan alat monitoring dapat digunakan untuk mengukur dan memantau nilai arus, tegangan, dan intensitas cahaya hasil dari panel surya. Fungsi dari memonitoring panel surya adalah untuk mengumpulkan data sebanyak-banyaknya dari beberapa parameter yang mempengaruhi fungsi kerja panel surya. Data-data hasil monitoring yang sangat banyak tersebut digunakan untuk menganalisis apakah panel surya bekerja dengan baik, untuk menganalisis dan menentukan rangkaian pendukung seperti kontroler yang tepat untuk digunakan pada pembangkit tenaga surya.

Beberapa peneliti sudah melakukan pengembangan dari sistem monitoring. Dalam perkembangannya, sistem monitoring sedikit demi sedikit berkembang dari yang hanya dapat memonitoring secara local [1], transmisi data menggunakan modem GSM [2], hingga sistem monitoring berbasis web [3]. Seiring perkembangan teknologi, perancangan sistem monitoring dan kontrol berbasis Internet of Things (IoT) akhir-akhir ini banyak dikembangkan. Aplikasi monitoring dan pengendalian berbasis IoT antara lain dikembangkan untuk mengontrol peralatan pada smart home dan monitoring status jaringan distribusi 
tenaga listrik berbasis teknologi IoT. Menurut Winasis dan kawan-kawan (2016), sistem monitoring berbasis IoT dapat menggunakan ThingSpeak sebagai media penyimpanan data hasil pengukuran arus, tegangan, dan intensitas cahaya.

Tujuan dari penelitian ini, adalah untuk merancang dan membuat sebuah alat monitoring untuk memantau nilai arus, tegangan, dan intensitas cahaya dari panel surya berbasis IoT menggunakan ThingSpeak, serta meninjau apakah alat monitoring tersebut dapat bekerja dengan baik dalam mengukur setiap parameternya dan mengirimkan data secara online.

\section{Perancangan}

Pada bagian ini akan dijelaskan mengenai perancangan alat monitoring panel surya berupa perangkat sensor.

A. Perancangan sistem

Pada rancangan sistem penelitian ini terdiri dari beberapa bagian, yaitu modul sensor yang terdiri dari sensor arus, sensor tegangan, dan sensor intenstas cahaya. NodeMCU digunakan sebagai prosesor yang mengolah dan mengirim data ke Thingspeak. Prinsip kerja sistem monitoring panel surya dapat dilihat pada Gambar 1.

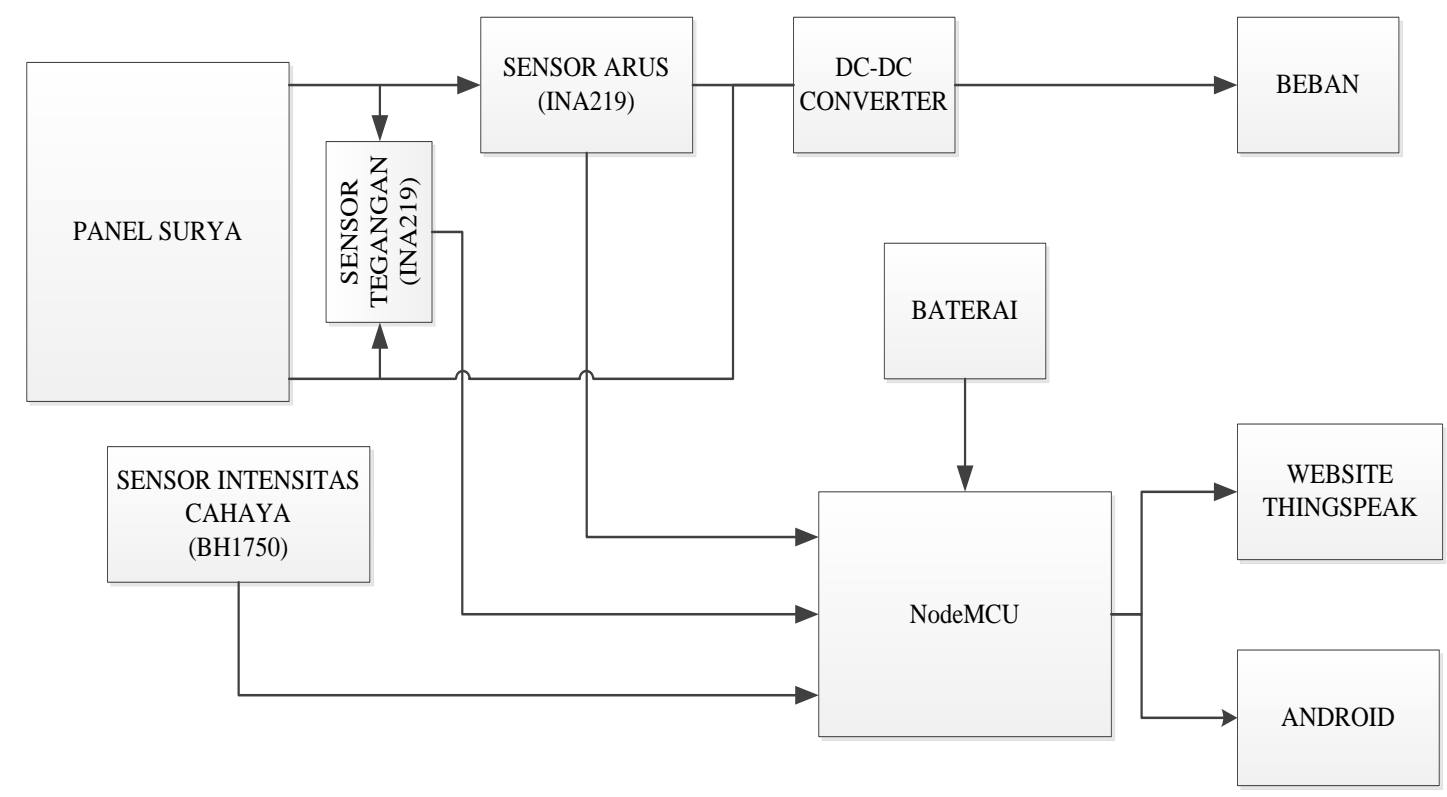

Gambar 1. Prinsip Kerja Sistem Monitoring Panel surya

\section{B. Perancangan elektronik}

Perancangan elektronik pada penelitian ini terdiri dari perancangan rangkaian sensor tegangan dan arus, sensor intensitas cahaya, dan perancangan rangkaian gabungan semua sensor.

1. Sensor Tegangan dan Arus 
Sensor tegangan dan arus yang digunakan untuk mengukur nilai arus dari panel surya pada alat monitoring ini adalah modul sensor INA219 yang merupakan sensor untuk mengukur arus dan tegangan DC. Gambar 3 menunjukkan gambar dari rangkaian INA219. Pengujian nilai pembacaan sensor dengan cara membandingkan hasil ukur dari alat ukut konvensional dengan hasil pengukuran sensor. Jika error pembacaan sensor kecil, maka dapat dikatakan bahwa rangkaian sensor arus sudah mampu membaca nilai arus dengan presisi. Konfigurasi pin-pin dari INA219 dapat dilihat pada Gambar 2.

INA219 mengukur arus yang mengalir (current shunt) dari resistor dengan mengukur nilai tegangan yang melintasi resistor dan kemudian menerapkan hukum ohm:

$$
\text { Ishunt }=\frac{\text { Vshunt }}{\text { Rshunt }}
$$

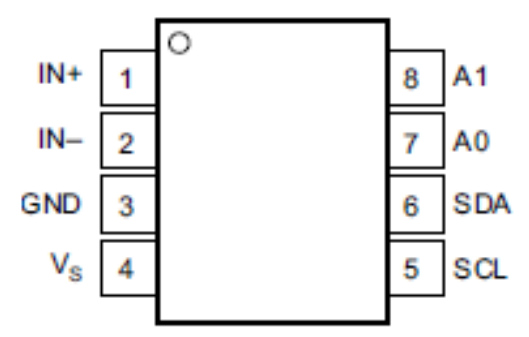

Gambar 2. Konfigurasi pin INA219

Untuk dapat mengukur nilai arus dan daya dapat dilihat pada persamaan berikut

$$
\begin{gathered}
I_{\text {register }}=\frac{\text { shunt V.register } * \text { calibration register }}{4096} \ldots . . . . \\
P_{\text {register }}=\frac{I_{\text {register }} * \text { bus V.register }}{5000} \ldots \text {..................... }
\end{gathered}
$$

Nilai dari calibration register hanyalah faktor penskalaan yang bergantung pada sistem yang mengubah tegangan shunt menjadi arus. Untuk menghasilkan persmaan baru dari current register dengan menggunakan hukum ohm pada persamaan arus shunt sebagai berikut:

$$
\begin{aligned}
& I_{\text {shunt }}=I_{\text {register }} * L S B_{\text {current }} \\
& I_{\text {register }}=\frac{I_{\text {shunt }}}{L S B_{\text {current }}}=\frac{V_{\text {shunt }}}{R_{\text {shunt }}} * \frac{1}{L S B_{\text {current }}} . .
\end{aligned}
$$

Nilai Vshunt diganti dengan persamaan 4 maka:

$$
I_{\text {register }}=\frac{\text { shunt V.register } * 10 \mu \mathrm{V}}{R_{\text {shunt }}} * \frac{1}{L S B_{\text {current }}} \ldots . . .
$$

Dengan menggabungkan kedua persamaan register, maka didapat persamaan untuk calibration register sebagai berikut:

$$
\frac{\text { shunt v.register } * \text { cal.register }}{4096}=\frac{\text { shunt v.register } * 10 \mu V}{R_{\text {shunt }}} * \frac{1}{L S B_{\text {current }}}
$$




$$
\text { Calibration register }=\operatorname{trunc}\left(\frac{0.04096}{L S B_{\text {current }} * R_{\text {shunt }}}\right) \cdots
$$

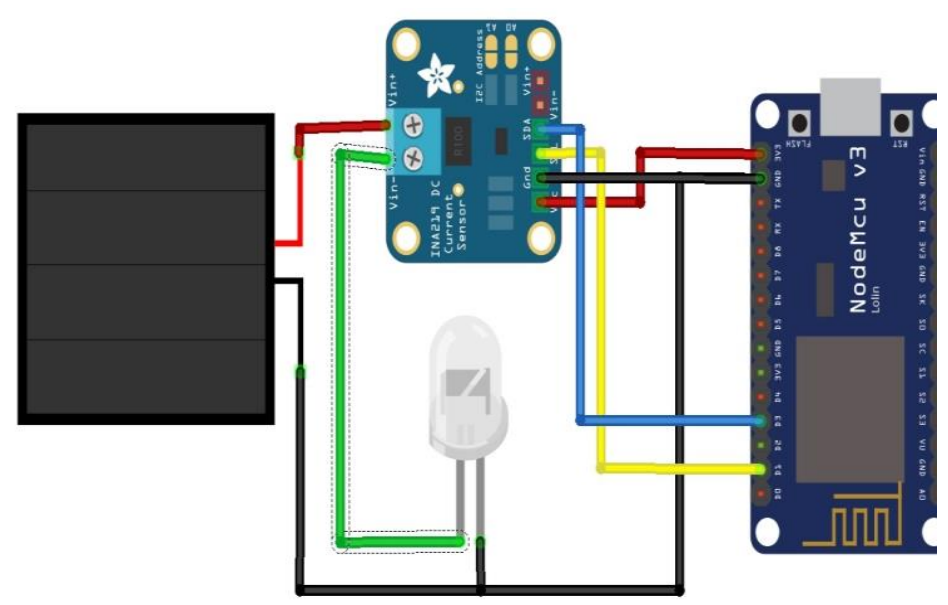

Gambar 3. Rangkaian Sensor Arus INA219 dengan beban lampu

\section{Sensor Intensitas Cahaya}

Pada penelitian ini, sensor intensitas cahaya yang digunakan untuk mengukur cahaya matahari yang merupakan salah satu parameter penting dalam sebuah pembangkit listrik tenaga surya adalah BH1750. BH1750 adalah modul sensor digital yang memiliki keluaran data yang sudah berbentuk satuan Lux. Pada penelitian ini, BH1750 dihubungkan dengan ESP8266 NodeMCU sebagai prosesor. Data hasil dikirimkan ke NodeMCU melalui komunikasi serial dengan menghubungkan SDA dan SCL dari BH1750 ke NodeMCU. Gambar 4 menunjukkan rangkaian dari BH1750 dengan NodeMCU. Pin SDA dari BH1750 terhubung ke pin D2 dari NodeMCU dan pin SCL dari BH1750 terhubung ke pin D1 dari NodeMCU.

Untuk mengkonversi nilai digital pembacaan sensor BH1750 kedalam satuan Lux digunakan persamaan berikut:

$$
L x=\frac{\text { nilai pembacaan sensor }}{1.2} .
$$

\section{Rangkaian Keseluruhan Sensor}

Perancangan rangkaian ketiga sensor saat digabung dapat dilihat pada Gambar 5 Penampilan data pada LCD bertujuan untuk menampilkan nilai murni hasil pembacaan sensor sebelum dikirimkan ke aplikasi ThingSpeak untuk di tampilkan melalui android. 


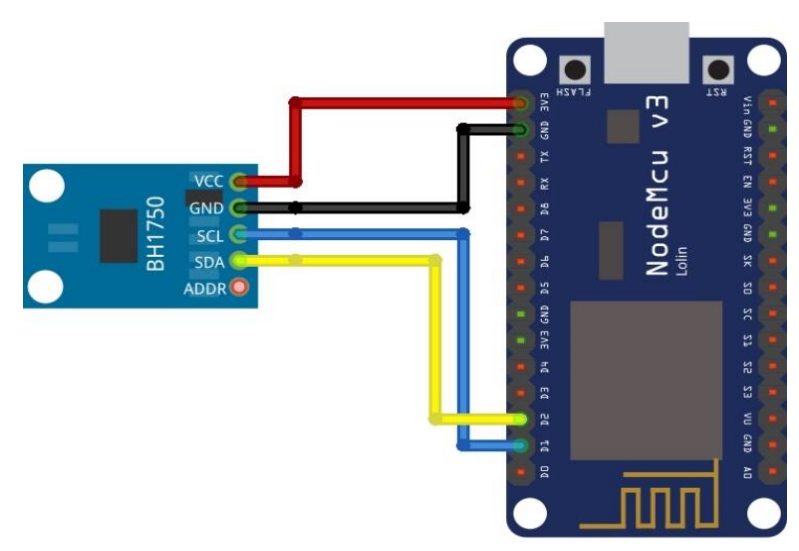

Gambar 4. Rangkaian Sensor BH1750

\section{Perancangan Software}

Pada sistem ini, komunkasi yang digunakan antara prosesor yang terhubung pada satu node dengan bagian pemantauan data hasil pembacaan sensor menggunakan modul ESP8226 wi-fi receiver. Sistem ini berfungsi sebagai pencatatan (logging) data, pengolahan data, serta penampilan data dengan dua tampilan. Tampilan data pertama menggunakan LCD 16x2 yang menampilkan data langsung hasil pembacaan sensor. Tampilan data kedua menggunakan layanan ThingSpeak yang merupakan platform untuk Internet of Things. Diagram alir dari perancangan software dapat dilihat pada Gambar 6. Aplikasi yang dapat dilakukan yaitu pengumpulan data sensor dan mengirimkan ke cloud sebagai media penyimpanan data hasil pengukuran. Data hasil pengukuran kemudian dapat di tampilkan pada Android pengguna melalui aplikasi ThingSpeak.

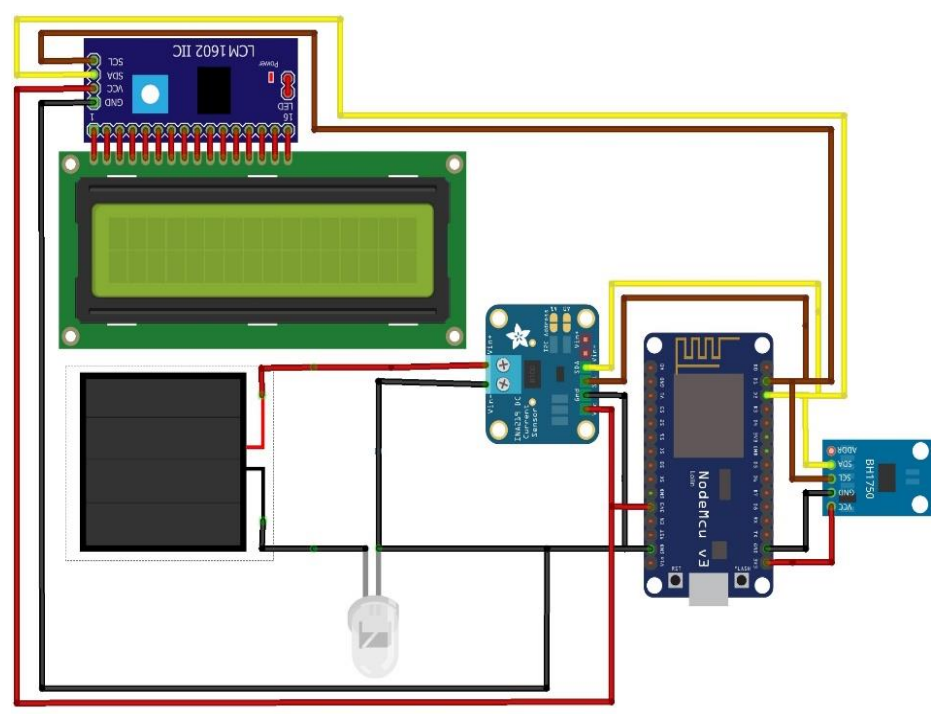

Gambar 5. Rangkaian Keseluruhan Sensor 


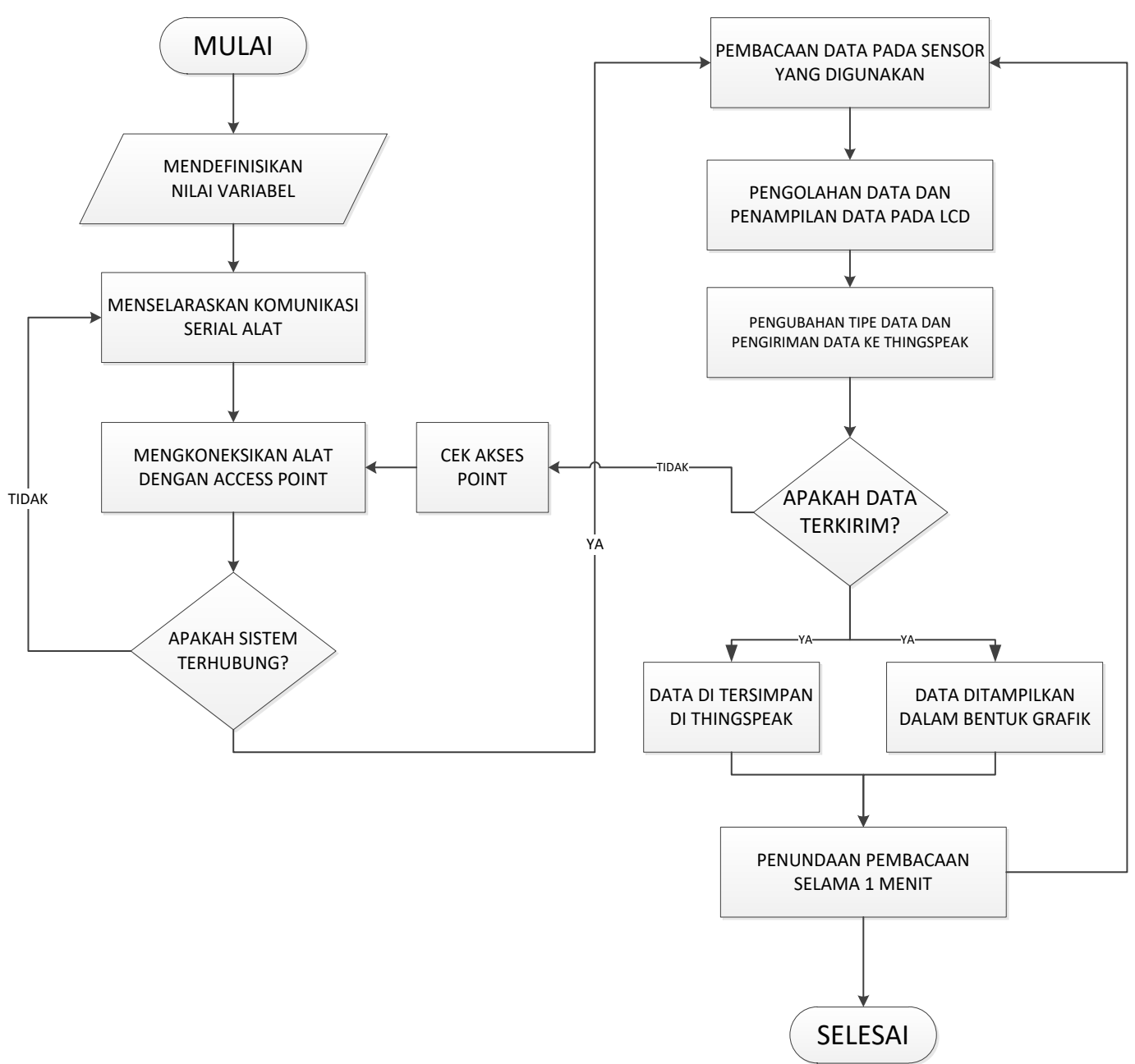

Gambar 6. Diagram alir perancangan software

\section{Hasil Penelitian dan Pembahasan}

Rangkaian dari alat monitoring yang telah jadi dapat dilihat pada Gambar 7(a). Pada gambar terdapat angka-angka untuk menjelaskan setiap komponen sebagai berikut:

1) ESP8266 NodeMCU

2) DC-DC Converter pertama

3) DC-DC Converter kedua

4) Pin untuk kabel dari baterai yang terhubung ke input buck converter.

5) Pin untuk kabel dari beban lampu DC $12 \mathrm{~V}$

6) Pin untuk kabel dari panel surya

7) INA219

8) Pin untuk menghubungkan modul sensor BH1750.

9) Pin untuk menghubungkan LCD

Gambar 7(b) menunjukkan bagian luar dari kotak kontrol alat sistem monitoring. Pada bagian luar kotak terdiri dari LCD untuk menampilkan nilai dari arus, tegangan, daya dan intensitas cahaya matahari yang dibaca oleh sensor. Selain itu terdapat tiga pin untuk menghubungkan beban, panel surya, dan baterai. 


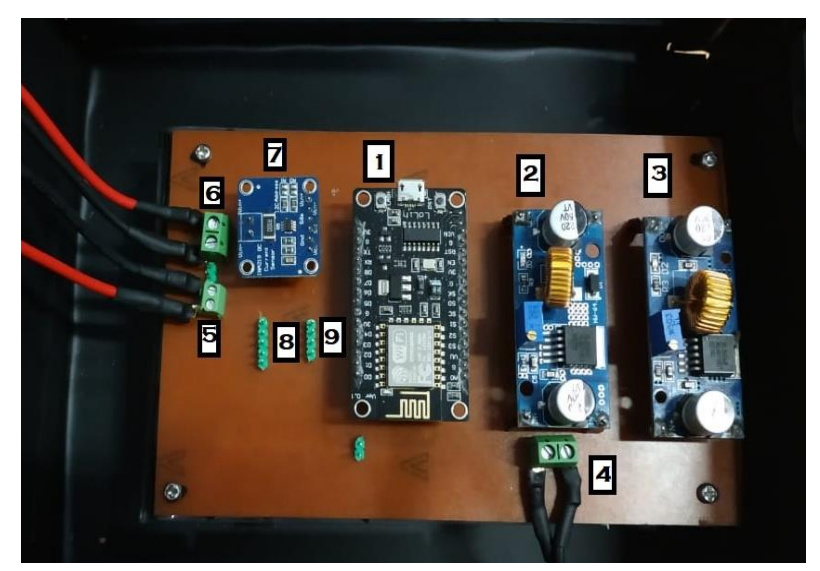

(a)

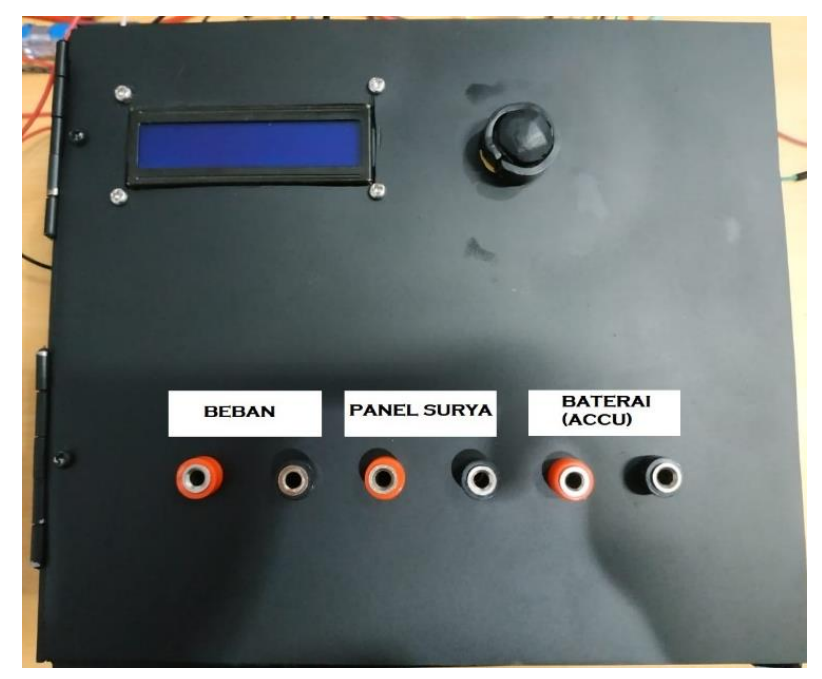

(b)

Gambar 7. (a) Board dari alat monitoring (b) bagian luar kotak panel kontrol dari sistem monitoring

\section{Sensor arus dan tegangan}

Pada penelitian ini pengukuran nilai arus dari panel surya dengan modul sensor INA219 yang merupakan sensor dengan menggunakan jenis komunikasi I2C. Pin SCL dan SDA masing-masing dihubungkan ke pin D1 (scl) dan D2 (sda) NodeMCU. Sedangkan pin VCC dan GND masing-masing dihubungkan ke pin 3.3V dan GND NodeMCU. Pada pengujian modul sensor INA219 ini dengan cara mengukur arus yang tegangannya divariasikan dengan beban yang sama yaitu lampu 5 watt dengan sumber tegangan dari power supply. Kemudian nilai yang terukur pada Amperemeter akan dibandingkan dengan nilai hasil pembacaan sensor. Data pengujian dari INA219 dapat dilihat pada Tabel 1 dimana didapat rata-rata galat adalah 1.08\%. Gambar dari grafik hasil pebacaan sensor arus yang dibandingkan dengan pembacaan amperemeter dapat dilihat pada Gambar 8. 


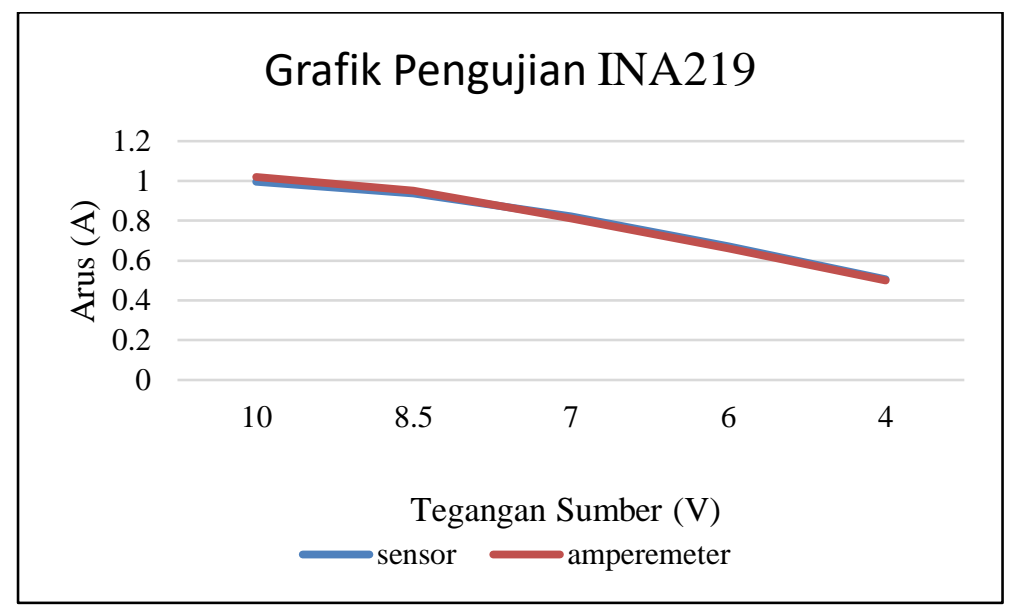

Gambar 8. Grafik pengujian nilai sensor arus

Tabel 1. Perbandingan nilai pembacaan sensor dengan multimeter

\begin{tabular}{|c|c|c|c|}
\hline Vs (V) & INA219 (A) & Multimeter (A) & Galat (\%) \\
\hline 10 & 0.996 & 1 & 0.4 \\
\hline 8.5 & 0.938 & 0.95 & 1.3 \\
\hline 7 & 0.822 & 0.81 & 1.5 \\
\hline 6 & 0.653 & 0.66 & 1.02 \\
\hline 4 & 0.506 & 0.50 & 1.2 \\
\hline \multicolumn{3}{|c|}{ Rata-rata nilai galat } & $1.08 \%$ \\
\hline
\end{tabular}

Pengujian modul sensor INA219 ini dilakukandengan cara mengukur tegangan dari sebuah catu daya yang tegangannya divariasikan. Kemudian nilai yang terukur pada voltmeter akan dibandingkan dengan nilai hasil pembacaan sensor. Data pengujian dari INA219 dapat dilihat pada Tabel 2 dimana didapat rata-rata galat adalah $0.66 \%$. Gambar dari grafik hasil pebacaan sensor tegangan yang dibandingkan dengan pembacaan voltmeter dapat dilihat pada Gambar 9.

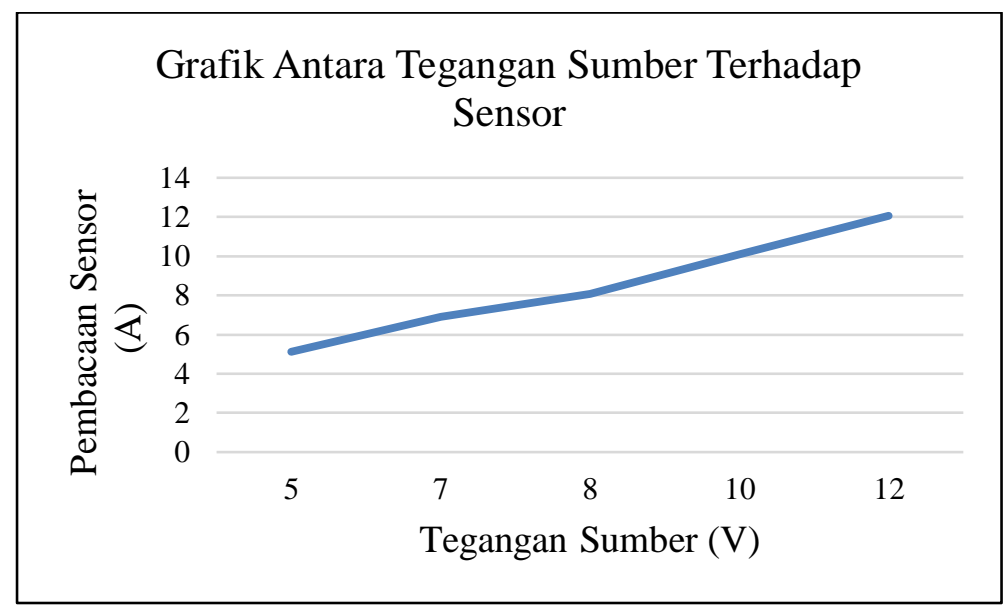

Gambar 9. Grafik pengujian nilai sensor arus 
Tabel 2. Perbandingan nilai tegangan dari pembacaan sensor dengan multimeter

\begin{tabular}{|c|c|c|}
\hline Sensor tegangan (V) & Multimeter (V) & Galat (\%) \\
\hline 5,03 & 5 & 0,6 \\
\hline 6,95 & 7 & 0.7 \\
\hline 8,06 & 8 & 0,5 \\
\hline 10,1 & 10 & 1 \\
\hline 12,06 & 12 & 0,5 \\
\hline \multicolumn{2}{|c|}{ Rata-rata nilai galat } & $\mathbf{0 , 6 6 \%}$ \\
\hline
\end{tabular}

2. Sensor intensitas cahaya

Pada penelitian ini, sensor yag digunakan untuk mengukur nilai intensitas cahaya matahari adalah BH1750VI yang hasil keluarannya langsung dalam satuan Lux. Dari hasil kajian pustaka ulang, didapat sensor yang mampu membaca nilai intensitas cahaya dengan tingkat ketelitian yang tinggi adalah BH1750 dengan rentang pembacaan $6500 \mathrm{~W} / \mathrm{m} 2$ atau 54612,50 Lux. Untuk membuktikan tingkat ketelitian dari sensor ini, maka dilakukan pengujian dengan cara membandingkan hasil antara pengukuran sensor BH1750VI dengan alat ukur konvensional yaitu Luxmeter. Dari pengukuran yang dilakukan, didapat data seperti pada Tabel 3. Dari hasil pengujian didapatkan persentase galat sebesar 1,01\%.

\section{Uji Coba Pengiriman data ke ThingSpeak}

Setelah dilakukan pengujian dari setiap sensor, kemudian dilakukan uji coba rangkaian. Pengujian rangkaian ini dilakukan untuk mengetahui apakah NodeMCU dapat bekerja dengan baik sebagai prosesor dalam menerima data dari ketiga sensor, pengolah data, dan juga dapat mengirim data dengan baik ke ThingSpeak. Pengujian rangkaian ini dilakukan meggunakan baterai 9V sebagai pengganti dari panel surya, sebuah LED dan resistor sebagai beban, sama seperti rangkaian sebeumnya yang diguakan untuk menguji sensor.

Dapat dilihat nilai tegangan, arus, dan intensitas cahaya dari sensor dapat dibaca dengan baik oleh NodeMCU sebagai prosesor. Hasil pembacaan sensor kemudian dikirim ke ThingSpeak oleh NodeMCU. Pada ThingSpeak, data yang diterima ditampilkan dalam bentuk grafik. Grafik hasil pembacaan sensor dapat dilihat pada Gambar 10.

Tabel 3. Perbandingan nilai pembacaan sensor dengan Luxmeter

\begin{tabular}{|c|c|c|}
\hline Nilai BH1750 (Lx) & Pengukuran luxmeter (Lx) & Galat (\%) \\
\hline 9373 & 9478 & 1,10 \\
\hline 9607 & 9730 & 1.26 \\
\hline 8462 & 8364 & 1.15 \\
\hline 11605 & 11720 & 0.98 \\
\hline 10543 & 10680 & 1.28 \\
\hline 11100 & 11195 & 0.85 \\
\hline 20656 & 20750 & 0.45 \\
\hline \multicolumn{2}{|c|}{ Rata-rata nilai galat } & $1.01 \%$ \\
\hline
\end{tabular}




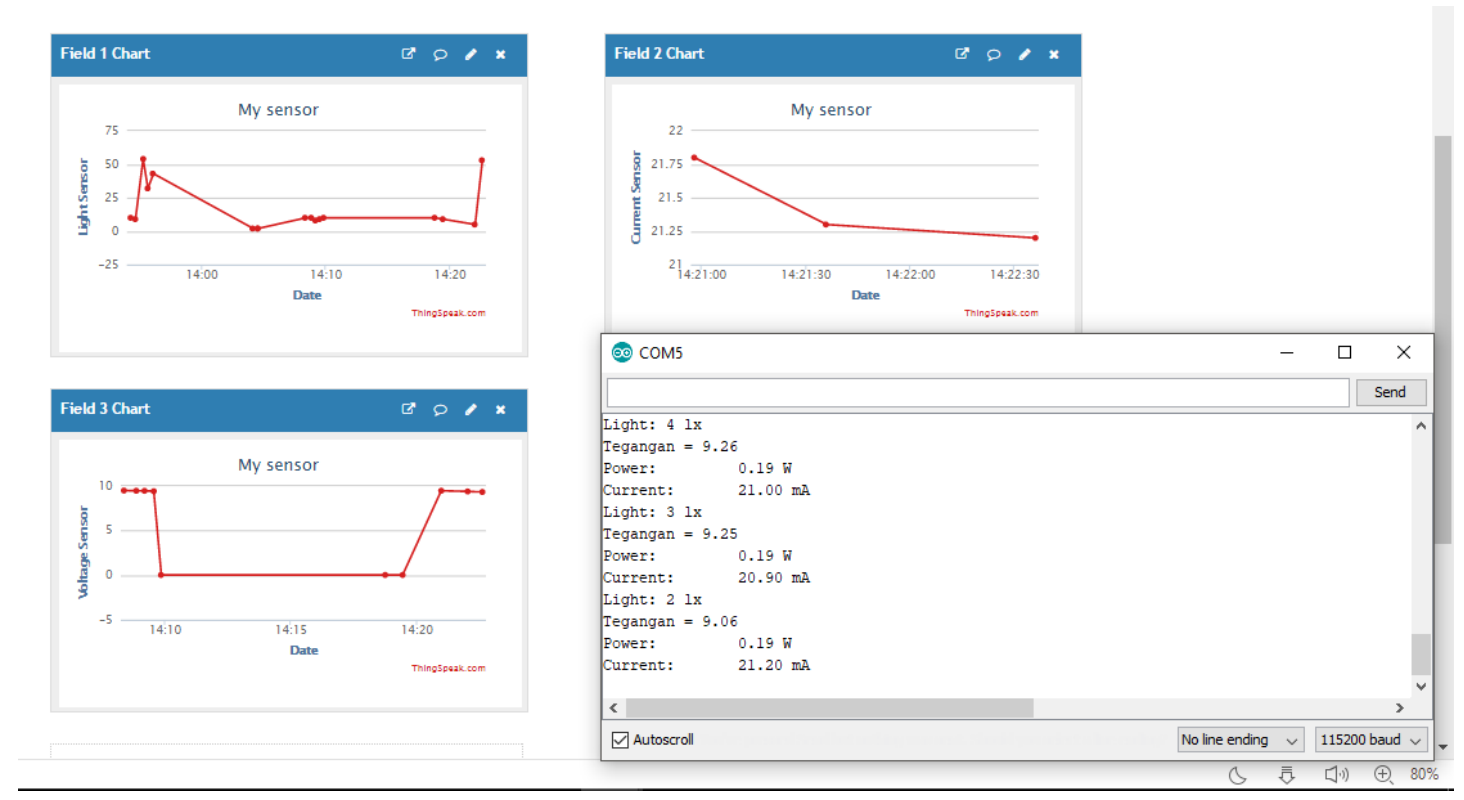

Gambar 10. Pengujian pengiriman data ke Thingspeak

\section{Pengambilan Data}

Pada peneitian ini dilakukan dua hari pengambilan data, hari pertama sebagai pengambilan data dengan tujuan untuk menguji alat monitoring dilkukan mulai pukul 10.00 WIB sampai pukul 15.00 WIB. Pada pengambilan data dihari pertama, didapatkan data yang tersimpan sebanyak 837 data. Data dikirim setiap 20 detik, data disimpan oleh ThingSpeak dalam bentuk file excel dan saat diunduh data berbentuk file excel. Grafik yang ditunjukkan pada ThingSpeak pada data hari pertama dapat dilihat pada Gambar 11.

Data kemudian dirangkum dengan cara mengambil sampel data setiap sepuluh menit. Pada pengambilan data hari pertama cuaca sedikit mendung. Dapat dilihat dari nilai intensitas cahaya matahari yang cukup kecil. Karena cuaca mendung panel surya tidak mendapatkan cahaya matahari yang cukup sehinnga nilai tegangan, arus dan daya sangat kecil. Cuaca mendung berangsung dari pagi hingga sore hari, akibatnya nilai dari seluruh variabel paling tinngi pada pukul 12.00 WIB yang merupakan dengan intensitas cahaya 16299 Lux, arus sebesar $216.6 \mathrm{~mA}$ atau $0.2166 \mathrm{~A}$, besar tegangannya $20.01 \mathrm{~V}$, dan daya yang dihasilkan panel surya sebesar 4.33. Grafik dari intensitas cahaya, tegangan, arus, dan daya pada rentang data setiap 10 menit.

Data yang dikirimkan ke ThingSpeak dengan data yang terbaca di LCD memiliki perbedaan waktu. Hal ini dikarenakan konektivitas internet yang menyebabkan terkadang terjadi keterlambatan pengiriman data ke ThingSpeak. Oleh karena itu dilakukan perbandingan antara data yang terbaca di LCD dengan data yang tampil pada situs ThingSpeak. 


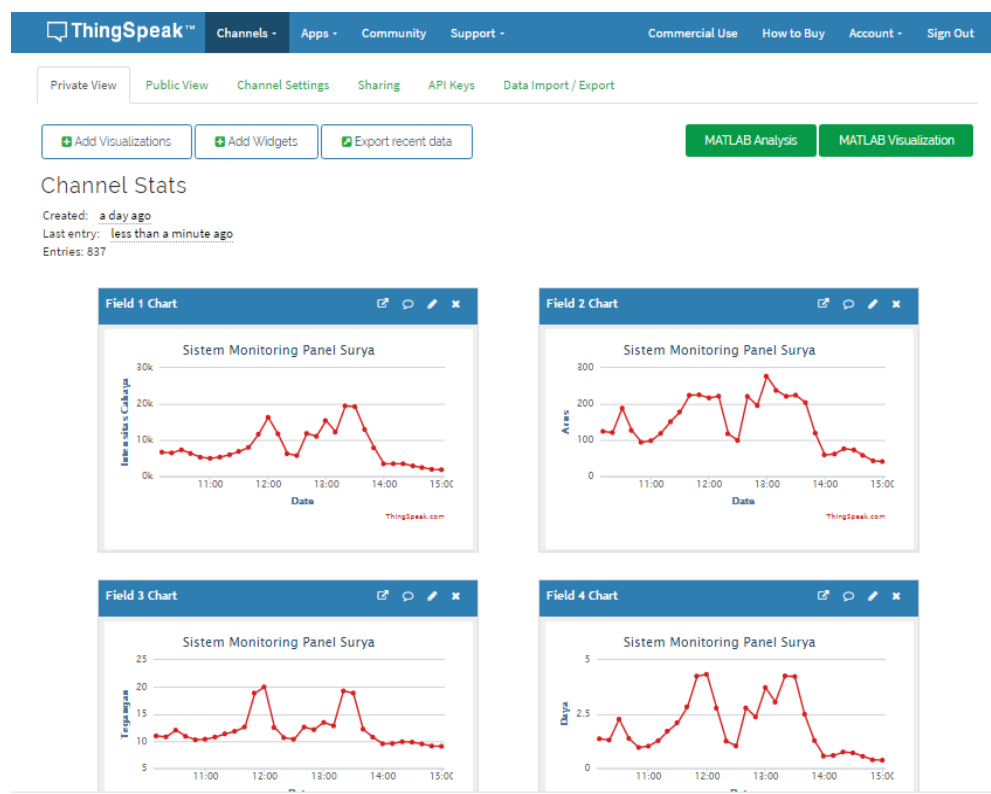

(a)

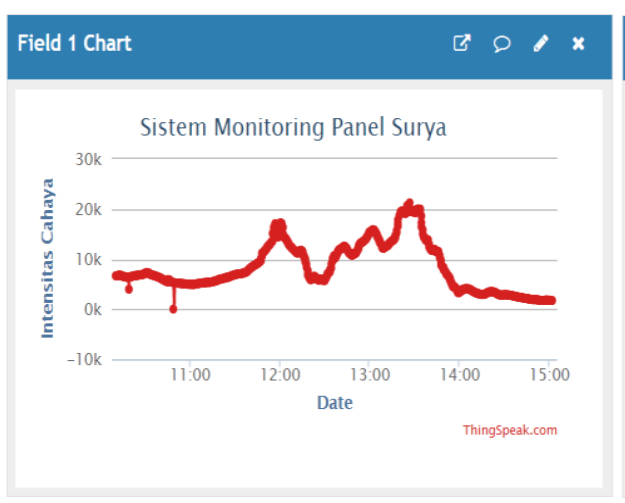

(b)

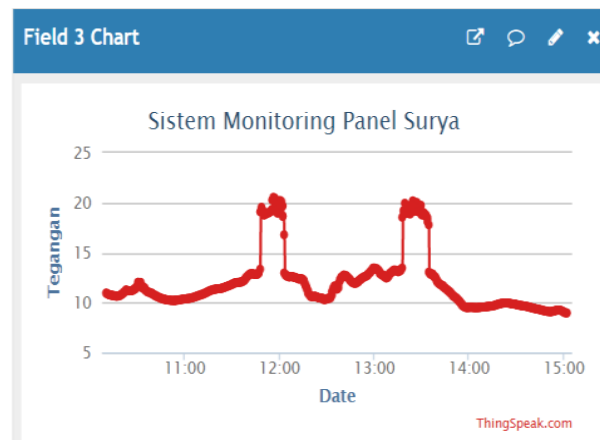

(d)

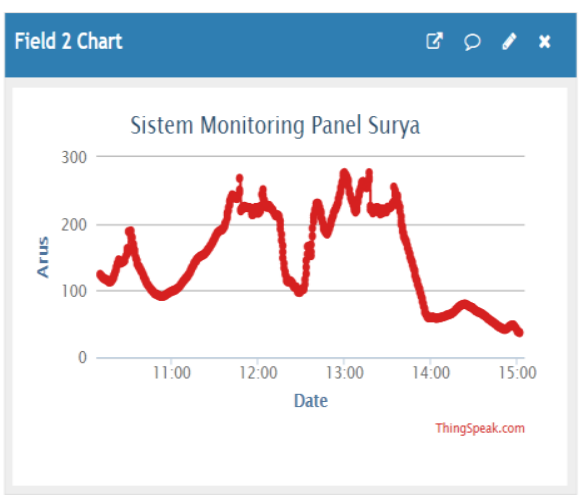

(c)

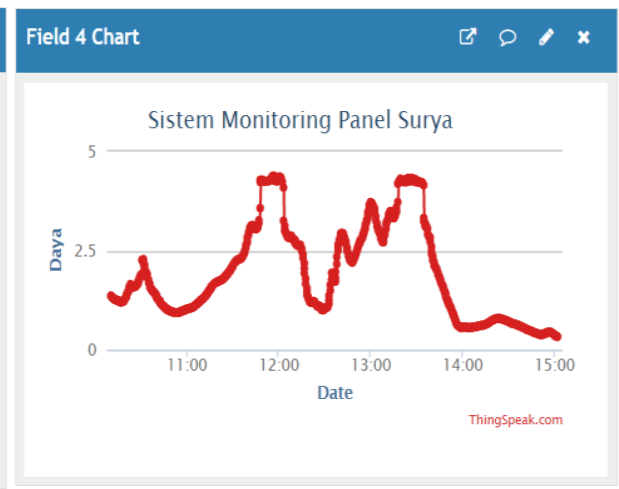

(e)

Gambar 11. Grafik data hari pertama pada ThingSpeak; (a) Tampilan keseluruhan grafik pada ThingSpeak; (b) Grafik intensitas cahaya; (c) Grafik arus; (d) Grafik tegangan; (e) Grafik Daya 
Pada peneitian ini dilakukan dua hari pengambilan data, hari kedua sebagai pengambilan data dimulai pukul 08.00 WIB sampai pukul 18.00 WIB. Pada pengambilan data dihari pertama, didapatkan data yang tersimpan sebanyak 1573 data. Data dikirim setiap 20 detik, data disimpan oleh ThingSpeak dalam bentuk file excel dan saat diunduh data berbentuk file excel.

Data kemudian dirangkum dengan cara mengambil sampel data setiap sepuluh menit. Pada pengambilan data hari kedua cuaca sangat cerah. Dapat dilihat dari nilai intensitas cahaya matahari yang lebih tinggi nilainya dibandingkan hari pertama. Karena cuaca cerah, panel surya mendapatkan cahaya matahari yang cukup sehingga nilai tegangan, arus dan daya lebih besar daripada hari pertama.. Seperti halnya pada hari pertama, data hari kedua juga dilakukan perbandingan waktu dari data yang terbaca oleh alat dan ditampilkan pada LCD dengan data yang terkirim ke ThingSpeak. Grafik data hari kedua dapat dilihat pada Gambar 12.

Selain dapat ditampilkan pada website Thingspeak, hasil monitoring juga dapat ditampilkan dalam aplikasi Thingspeak pada android. Tampilan android dari sistem monitoring dapat dilihat pada Gambar 13.

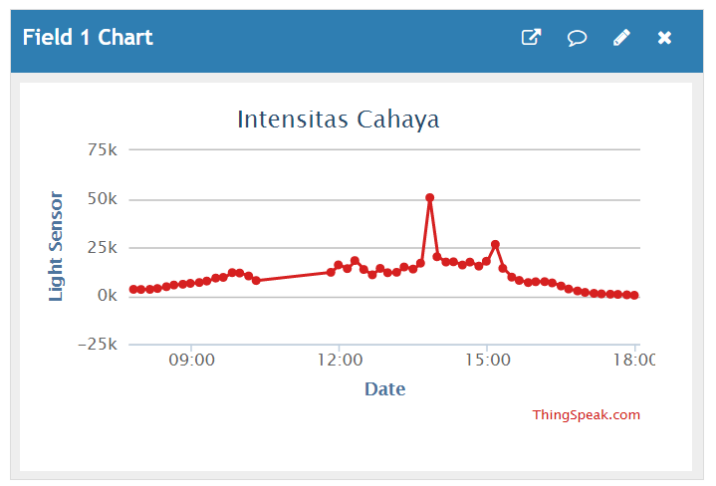

(a)

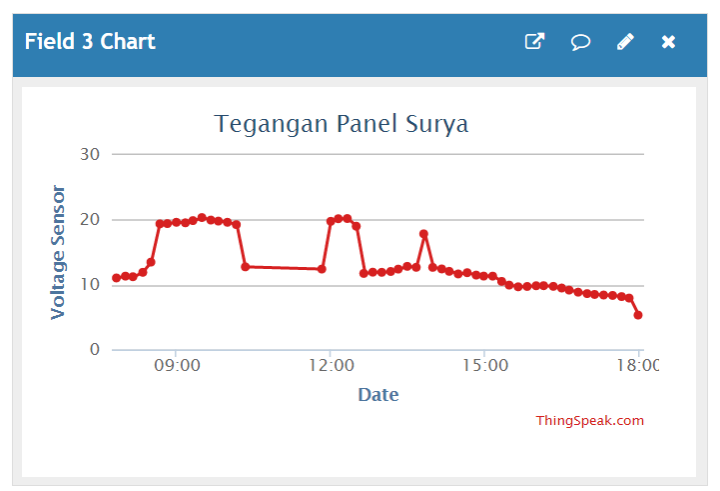

(c)

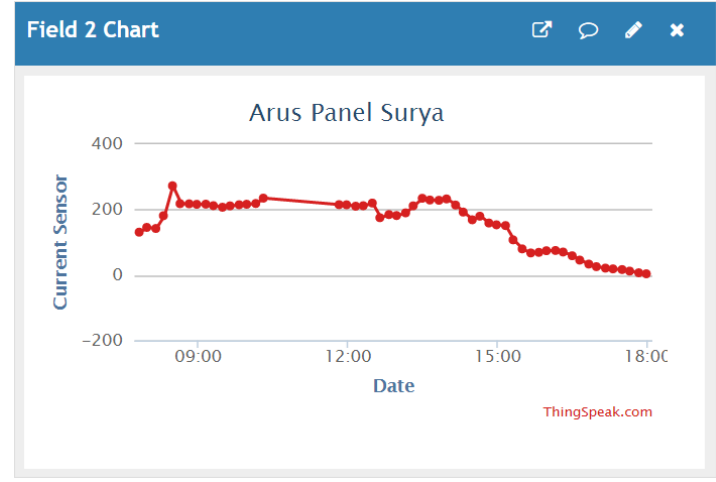

(b)

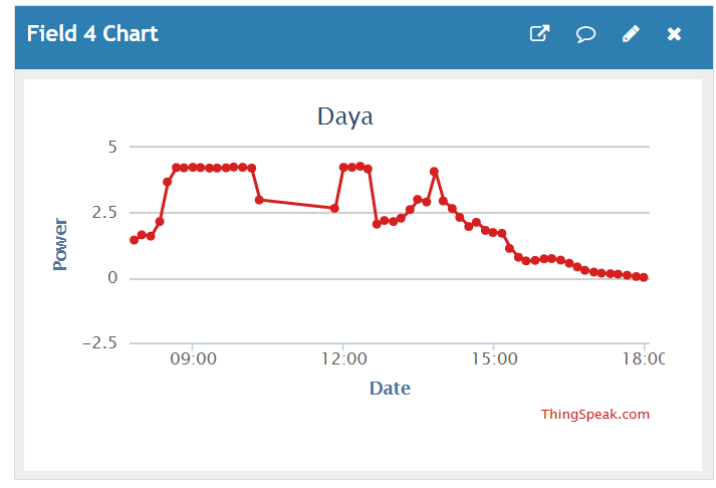

(d)

Gambar 12. Grafik data hari kedua setiap 10 menit; (a) Intensitas cahaya; (b) Arus; (c) Tegangan; (d) Daya 


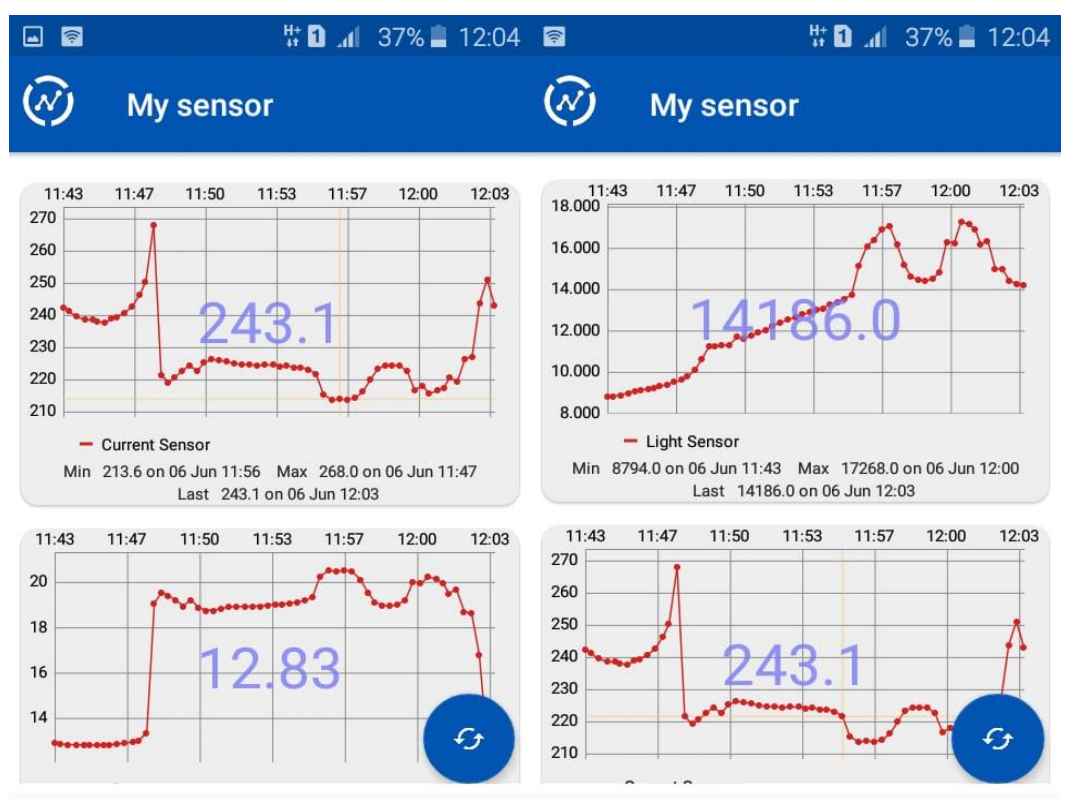

Gambar 13. Tampilan android

\section{Kesimpulan dan Saran}

A. Kesimpulan

Dari penelitian yang telah dilakukan, dapat ditarik beberapa kesimpulan sebagai berikut:

1. Sensor INA219 dapat mengukur nilai tegangan panel surya dengan cukup baik yang memiliki persentase galat sebesar $0,66 \%$. Selain mengukur tegangan, dalam mengukur arus dari panel surya yang disambung beban lampu DC 5 Watt memiliki persentase galat sebesar 1,08\%. Dari besar persentase tersebut dapat disimpulkan bahwa sensor INA219 dapat mengukur nilai intensitas cahaya dengan cukup presisi. Sensor intensitas cahaya BH1750 dalam mengukur intensitas cahaya matahari memiliki persentase galat sebesar 1,01\%. Dari besar persentase tersebut dapat disimpulkan bahwa sensor BH1750 dapat mengukur nilai intensitas cahaya dengan cukup baik.

2. Hasil monitoring panel surya dapat ditampilkan dengan baik pada website Thingspeak dalam bentuk grafik, dan dapat ditampilkan pula pada aplikasi Thingspeak di android. Thingspeak juga bekerja dengan baik sebagai media penyimpanan data monitoring yang dilakukan.

3. Pengiriman data-data dari nilai arus, tegangan, dan intensitas cahaya yang merupakan parameter yang diukur oleh alat monitoring ThingSpeak berjalan dengan baik. Selisih waktu dari pembacaan alat dan data yang diterima oleh website berkisar selam 4-6 detik. Hal ini dikarenakan koneksi internet yang menyebabkan terkadang adanya keterlambatan pengiriman data. Data-data yang diterima oleh Thingpseak dapat dibaca dan dilihat melalui situs resmi ThingSpeak dalam bentuk data dalam format Ms Excel atau dalam bentuk grafik.

B. Saran

Dari hasil penelitian yang telah dilakukan, saran yang dapat diambil adalah untuk media dalam memonitoring agar lebih bervariasi atau lebih lengkap menu-menu yang dibutuhkan dapat membuat website tersendiri, dan alat akan lebih tepat waktu dalam mengirimkan data jika menggunakan RTC untuk menentukan waktu alat mengirimkan data pada jam tertentu. 


\section{Daftar Pustaka}

[1] Mohamed Zahran dkk, "LabView Based Monitoring System Applied for PV Power Station," Proceedings of the 12th WSEAS International Conference on Automatic Control, Modelling \& Simulation, 2010.

[2] Farihah Shariff, Nasrudin Abd Rahim, Hew Wooi Ping, "Photovoltaic Remote Monitoring System Based on GSM," IEEE Conference on Clean Energy and Technology (CEAT), 2013.

[3] Kopacz Cs. dkk, "Remote and Centralized Monitoring of PV Power Plants," International Conference on Optimization of Electrical and Electronic Equipment OPTIM, 2014.

[4] Winasis, Azis Wisnu Widhi Nugraha, Imron Rosyadi, Fajar Surya Tri Nugroho, "Desain Sistem Monitoring Sistem Photovoltaic Berbasis Internet of Things (IoT)," JNTETI Vol. 5, vol. 5, 2016.

[5] Afrizal Fitriandi, Endah Komalasari, Herri Gusmedi, "Rancang Bangun Alat Monitoring Arus dan Tegangan Berbasis Mikrokontroler dengan SMS Gateway," Jurnal Rekayasa dan Teknologi Elektro, vol. X, 2016.

[6] S. Manai, Membuat Sendiri Pembangkit Listrik Tenaga Surya, Singapura: BukuDigital, 2014.

[7] M. Miller, The Internet of Things, Amerika: QUE, 2015.

[8] M. Ramdhani, Rangkaian Listrik, Bandung: STT Telkom, 2005.

[9] Frederick J. Bueche dan Eugene Hecht, Fisika Universitas, 10 ed., Jakarta: Erlangga, 2006.

[10] M. Abdullah, Fisika Dasar II, Bandung: Institut Teknologi Bandung, 2017.

[11] N. Hilalliati, "Rangkaian Pembagi Tegangan, Arus, dan Setara," 2014.

[12] K. Wardana, "Narin Laboratory," 2017. [Online]. Available: https://tutorkeren.com. [Accessed 20 Juli 2018].

[13] Allegro MicroSystems, LLC, "Fully Integrated, Hall Effect-Based Linear Current Sensor IC with 2.1 kVRMS Isolation and a Low-Resistance Current Conductor," Allegro MicroSystems, LLC, 2017.

[14] S. Soeparman, Teknologi Tenaga Surya, Malang: Universitas Brawijaya Press (UB Press), 2015.

[15] K. Jäger, Solar Energy Fundamentals,Technology,and Systems, Belanda: Delft University of Technology, 2014.

[16] P. H. Zweibel, Basic Photovoltaic Principles and Methods, USA: United States Government, 1982.

[17] G. M. Masters, Renewable and Efficient Electric Power Systems, New Jersey: John Wiley \& Sons, Inc, 2004.

[18] Thingspeak, "Thingspeak master," 28 Oktober 2014. [Online]. Available: https://github.com/iobridge/thingspeak/blob/master/README.textile.

[19] Mathworks, "ThingSpeak Support from Desktop MATLAB," 20 Desember 2018. [Online]. Available: https://www.mathworks.com/hardware-support/thingspeak.html.

[20] Luque dan Hegedus, Handbook of Photovoltaic Science and Engineering, 2 ed., USA: Wiley, 2011. 